\title{
Degradation of geosystems in the Belgorod region as a result of the economic activities
}

\author{
Yu. G. Chendev *, A. N. Petin, E. V. Serikova, and N. N. Kramchaninov \\ Belgorod State University, Belgorod
}

Received 25 October 2007

\begin{abstract}
We determined the rates of anthropogenic degradation of vegetation cover, soils, the river network, the slope type of terrain, and of the geological framework of landscapes. A decrease of the anthropogenic transformation rate of the component composition of geosystems was revealed in the biogenic components - bio-inert components - abiogenic components series was revealed. The time of complete exhaustion of the natural-resource potential is forecast from the components of the physical-geographical environment.
\end{abstract}

Keywords: anthropogenic degradation of natural environment, components of natural systems, Belgorod region.

\section{Introduction}

The Belgorod region, situated on the southern macroslope of the Middle Russian Upland, has gone through a long history of military-strategic and economic development. Most of the region belongs to the territory of the Central ForestSteppe of the Eastern-European Plain. The region was confronted with ecological problems as early as the $19^{\text {th }}$ century caused by the exhaustion of the old arable lands, destruction of forests, and by the shallowing of the rivers [1-3]. In the latter part of the $20^{\text {th }}$ century, they were complemented with a new set of challenges caused by air, water and soil cover pollution by emissions from motor vehicles, chemical ingredients from industries and agriculture $[4,5]$, disturbances of the lithogenic and hydrogeological framework of landscapes as a result of the increase in the area occupied by residential centers, quarries, and dumps [6-8].

In connection with the long-lasting, temporarily directed increase in anthropogenic effects on natural landscapes, it is of very high current importance to calculate the rate of change in the reserves of the region's natural geosystem components, and to predict the time of their total exhaustion provided the ongoing intensity of their utilization remains unchanged.

\section{The research methodology and techniques}

We identify arbitrarily the components of natural environment that have persisted on the territory of the Belgorod

\footnotetext{
* Corresponding author.

E-mail address: Chendev@bsu.edu.ru (Yu. G. Chendev).
}

region to date, as all areas have been and are undergoing direct or indirect anthropogenic effects. For that reason, the case in point can be either a high or a low degree of similarity of the objects we observe, to their natural counterparts.

In this paper we analyze the influence of the economic activities on such components of natural environment as vegetation, soil cover, river network, relief, and lithogenic framework of landscape. These components are three-dimensional bodies (except for the relief which can be represented mathematically as a "crumpled" plane).

We categorize the methods of anthropogenic transformation of the natural environment in the Belgorod region as three-dimensional bodies into four types: a) total-lateral transformation of the component (clear forest felling, continuous ploughing up of the steppes); b) focal-lateral transformation of the component (sporadic, nonunifrm decrease in the length and density of river network, gullying, and formation of quarries and dumps - in the last case two-component anthropogenic geological facies are produced, which consist of fill-up earth materials and naturally occurring materials buried beneath them); c) total-radial, and d) focal-radial transformation of the component where there is taking place a stadial decrease in its thickness from the top downward (shallowing of the rivers, sheet erosion of soils, dehumification of the soil profiles). Based on the aforementioned peculiarity of anthropogenic transformation of the components of physical-geographical environment, calculations of the rates of change and the predicted time of total exhaustion of some of them should be carried out in terms of the surface area as well as in terms of the mass (or, more exactly, of the reserves of the component) per unit time. 
This paper is based on many years of these authors' research on the history of economic development of the natural environment in the Belgorod region, including the analysis of publications spanning the time interval since the prerevolution era till the present, archival materials (including manuscripts from the $17^{\text {th }}$ century) as well as cartographic sources from different times. This study uses the historicalgeographical, comparative and mathematical methods of investigation.

\section{Destruction of the component structure of natural environment in the Belgorod region}

Vegetation cover. According to a reconstruction reported in [9], the area occupied by steppes during the pre-cultural period (the end of the $16^{\text {th }}$ century) constituted about $50 \%$ of the total area of the Belgorod region, and forests occupied about $45 \%$ of the territory. Clearly pronounced anthropogenic changes in vegetation cover of the steppes began in the $16^{\text {th }}$ century when Tatar roads (sakm) emerged [10]. Dramatic disturbances of the then existing steppe vegetation were caused by a transformation of the natural vegetation cover on the Tatar sakms as well as by steppe fires. On the territory of the Belgorod region during he $16^{\text {th }}-17^{\text {th }}$ centuries the total area of phytocenoses that were modified by trampling and packing of soils on Tatar roads was a few tens of square kilometers, while the total area of annually emerging pyrogenic landscapes could reach several tens or even hundreds of square kilometers [11]. Ploughing-up as the destructive factor in relation to the natural vegetation cover became important in the $18^{\text {th }}$ century.

Transformation of forests, when compared with transformation of steppe vegetation, occurred with some delay. The forests were affected primarily by the construction of residential centers and fortifications. The mean yearly consumption of timber by the population of the Belgorod region in the $17^{\text {th }}$ century was about $1000000-1200000$ cubic meters, which was equivalent to the destruction of 20-25 sq km/year of mature oak forest. At the end of the $17^{\text {th }}$ - first half of the $18^{\text {th }}$ century, timber was used in particularly large volumes in the construction of the Azov - Black Sea Flotilla [12]. During that period the yearly mean consumption of timber increased at least 5 times against the $17^{\text {th }}$ century. For that reason, as early as the end of the $18^{\text {th }}$ century the forests on the territory of the southern part of the Kursk region ruled by Governor-General (the western and middle parts of the contemporaneous territory of the Belgorod region) turned into only partly stocked stands, with solely young scrub wood and single banded trees growing there [13].

The spatio-temporal changes in natural vegetation on the territory of the Belgorod region over the course of the last 400 years are provided in Fig. 1. In the 1780s virgin steppes occupied about $22 \%$ of the region's total area, and only $16 \%$ corresponded to forests. By the mid- $19^{\text {th }}$ century forests occupied only $13 \%$, while the territory of nonarable lands decreased dramatically. In the 1880 s islands of virgin steppe

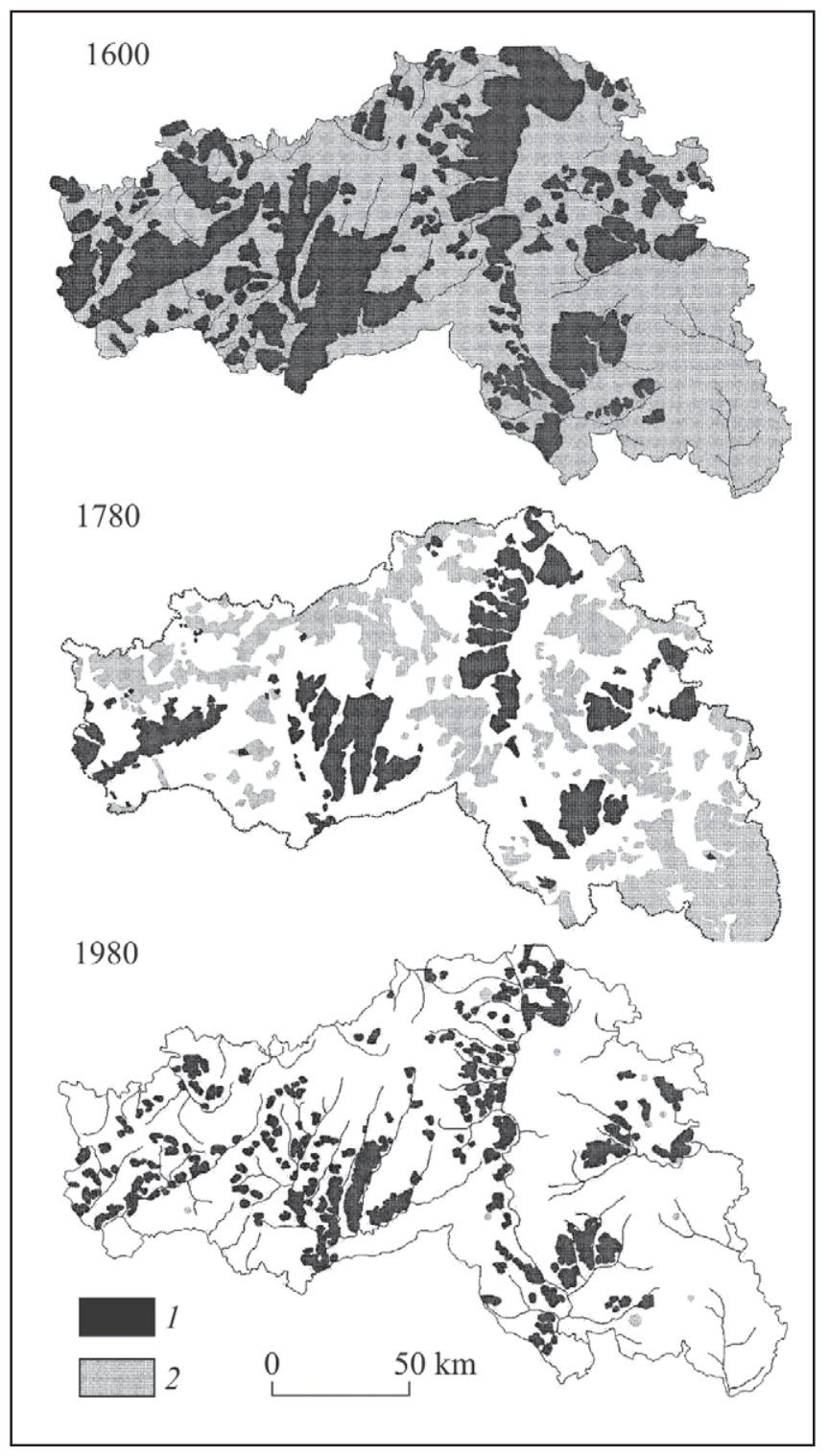

Fig. 1. Changes (across time) in areas pf natural vegetation on the territory of the Belgorod region (compiled using stock archives, and published and cartographic materials spanning different time intervals).

1 - forests, 2 - steppes.

remaining in ploughed up areas occupied not more than $20 \mathrm{sq} \mathrm{km}$, and such islands did not change very much since then. The decrease in the percentage of forest land continued till 1917 when the areas of forest-clad territories stabilized at $9 \%$ level of the region's area.

Thus the natural steppe vegetation suffered losses in $99.92 \%$ of the area which they had occupied prior to intensive development. The degradation rate of the areas and reserves of steppe vegetation averaged $3.6 \%$ for 10 years for the time interval 1600-1880. The total losses of the forest-clad area from 1600 to 1917 constituted $80 \%$ of the initial figure. At the pre-cultural period the reserves of the above-surface phytomass in the forests were estimated at $300 \mathrm{t} / \mathrm{ha}$ as a mini- 
mum (the characteristics of centuries-old broad-laved forests in the nature reserves of the Central Black-Earth Zone [14]); according to the data from the State Forest Reserves Administration of the Belgorod region, currently this figure does not exceed $150 \mathrm{t} / \mathrm{ha}$. Considering that on the study territory the forests with excessive felling were dominant as early as the $19^{\text {th }}$ century $[15,16]$, the losses of the reserves of the forest phytomass could total $90 \%$ of the level of natural forest ecosystems in the early $17^{\text {th }}$ century, and every 10 years over the course of the $17-19^{\text {th }}$ centuries the total reserves of the forest phytomass declined by $2.8 \%$, on average, of the initial figure.

Soil cover. Ploughing up was the oldest factor of anthropogenic influence on soil cover $[17,18]$. Nowadays the area of arable lands on the territory of the Belgorod region makes up $61 \%$ of the region's total area, whereas in the early $20^{\text {th }}$ century it was even larger, 71\% [19].

As calculations showed [20], in the virgin soils of the territory under investigation the weighted-mean content of humus in a $0-20 \mathrm{~cm}$ layer could constitute $8.2 \%$, and its stock in a one-meter thick layer could be $550 \mathrm{t} / \mathrm{ha}$. The weightedmean content of humus in the arable soil layer to date makes up $4.81 \%$ of the soil mass, and its reserves in a one-meter thick layer are $420 \mathrm{t} / \mathrm{ha}$. Therefore, in the arable soil layer the losses of organic matter for the entire period of agricultural development (given 240 years the mean age of the regions contemporaneous landscapes) could make up $41.5 \%$ of the original reserves (the loss rate of $1.7 \%$ in relative content for 10 years), and for a $0-1-\mathrm{m}$ thick layer we have $23.6 \%$ of the initial reserves (with the loss rate of $0.95 \%$ for 10 years).

The total losses of organic latter consist of two components: mineralization as a result of the "ploughing off" and removal together with the upper soil layers through erosion. Taking into account the percentage of eroded soils in the soil cover of the region's arable land (the arable lands making up $49.9 \%$ [17]), it was established that on absolutely even surfaces for the entire period of development the mean rate of dehumification (as a result of the "ploughing off") within the soil layer $0-20 \mathrm{~cm}$ thick constituted $0.06 \%$ of the humus content for 10 years, while on the sloping surfaces for an identical layer we have $0.22 \%$ of humus for 10 years. On the sloping lands the loss rate of humus due to erosion correlated with the loss rate as a result of the "ploughing off" as 3:1.

The river network. Analysis of the river network maps for he late $18^{\text {th }}$ century and the late $20^{\text {th }}$ century (Fig. 2) revealed the following changes. Two hundred years ago the total length of the river network within the Belgorod region was estimated at $6000 \mathrm{~km}$, with its density averaging 0.22 $\mathrm{km} / \mathrm{km}^{2}$. At the end of the $20^{\text {th }}$ century the length of the river network decreased by $4250 \mathrm{~km}$, with its density averaging $0.16 \mathrm{~km} / \mathrm{km}^{2}$, and the rate at which the river network was decreasing in its length averaged about $9 \mathrm{~km}$ per year. When compared with the end of the $18^{\text {th }}$ century, the length of the river network decreased by $29.2 \%$.

The length of the river network within the territory under investigation during the pre-cultural period (before the mid$17^{\text {th }}$ century) is unknown. During the implementation of the General Land Surveying Project, however, the forest lands in the region having the water-protective and water-regulation role had been disturbed greatly by human activity [13] (see Fig. 1). It is therefore reasonable to suppose that the decrease in the length of the rivers over the course of the last 350 years totaled at least $35 \%$ of their original state.

The relief and lithogenic framework of natural landscapes. The slopes of natural topography on the territory of the study region have been modified through gullying since the emergence of arable lands [19]. During the entire period of agricultural development the density of gullies totaled 0.5 $\mathrm{km} / \mathrm{km}^{2}$, with the mean area occupied by these anthropogenic landforms amounting to $263 \mathrm{~km}^{2}(0.97 \%$ of the region's total area). The mean growth rate of the gully network is estimated at $56.5 \mathrm{~km} /$ year, and the annual withdrawal of the lands by gullies is $1.1 \mathrm{~km}^{2}$, or $0.087 \%$ of the total area of the natural slopes for each 10 years.

The mineral component of the natural landscapes was experiencing anthropogenc transformation through the effects of three main processes: linear erosion, sheet erosion, and the establishment of quarries and dumps.

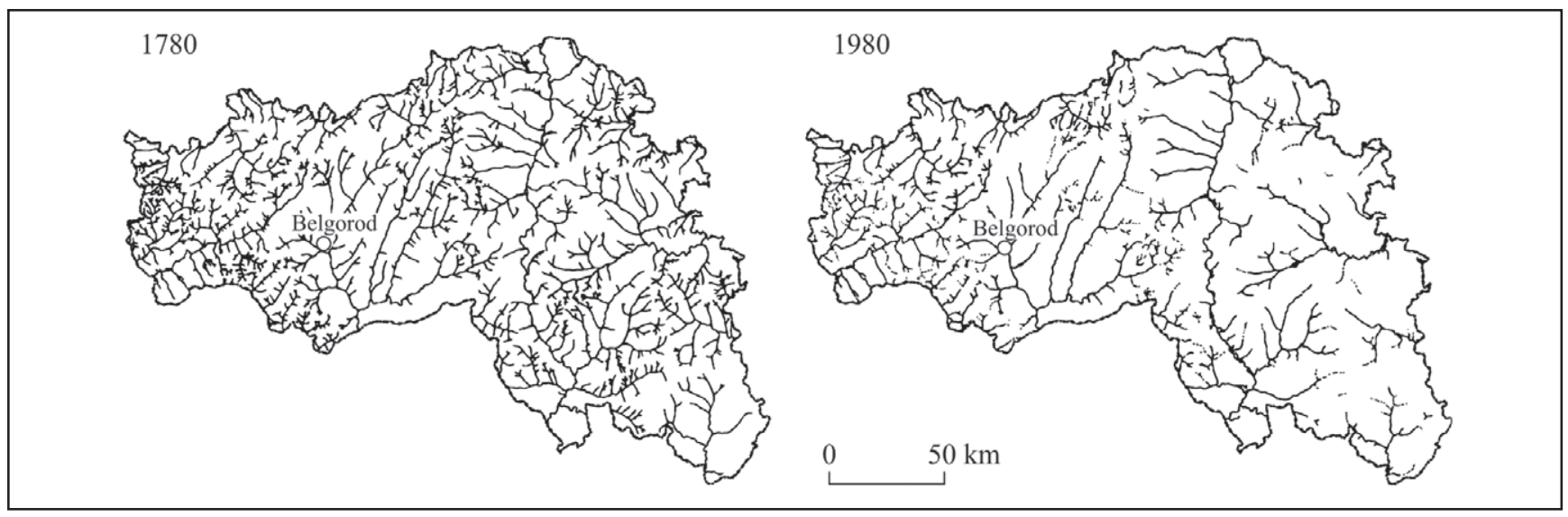

Fig. 2. River network of the Belgorod region at different historical periods (from cartographic materials of General Land Surveying [2136], and at present [37]). 
As calculations showed [38], the volume of soils and soil-forming earth materials that were eroded through gullying on the regions territory was $2-2.5 \mathrm{~km}^{3}$. Taking into consideration the volumes of eroded earth materials, the area and density of the contemporaneous gully network as well as the geometric shape of the gullies, it was found that for the entire period of agricultural development of the territory of the Belgorod region the mean rate of erosion-induced withdrawal of earth materials on sloping lands must constitute $0.065 \%$ for 10 years.

Throughout the period of exploitation of the arable soils, the volume of their sheet erosion within the territory under consideration was $0.984 \mathrm{~km}^{3}$ [38]. Arable lands with the surface steepness in excess of $2^{\circ}$ (where surface erosion manifests itself) occupy $49.9 \%$ of the total arable area in the Belgorod region $\left(8260 \mathrm{~km}^{2}\right)$. The layer of fine earth materials that was eroded throughout the entire period of ploughing up was $12 \mathrm{~cm}$ thick, with the denudation rate of $0.5 \mathrm{~cm}(0.4 \%$ of the mean thickness of the sloping soil profiles) every 10 years, which is equivalent to an annual loss of $6 \mathrm{t} / \mathrm{ha}$ of fine earth materials contained in the soil. The calculated denudation rate of the arable soils on the slopes $(0.5 \mathrm{~mm} /$ year $)$ exceeds the natural formation rates of the humus profile of the forest-steppe soils which are estimated at $0.35-0.45 \mathrm{~mm} /$ year [39]. Consequently, one can expect a directed reduction in the thickness of the humus and soil profiles on the slopes right up to total destruction of the soils.

The operation of quarries and dumps on the region's territory has been manifest only during the last 60 years. Nowadays the area of lands disturbed by this kind of activity is $450 \mathrm{~km}^{2}(1.7 \%)[6,40]$. The greatest transformation of lithosphere is observed on the territory of the mining industries of the Kursk Magnetic Anomaly, i.e. in the northern part of the region. Only on the territory of the Lebedinsky GOK the area of lands occupied by tailing dumps was $20 \mathrm{~km}^{2}$, while the dumps of overburden rock occupy $250 \mathrm{~km}^{2}$ at present [6]. The mean rate at which the area of the quarries, dumps and tailing dumps increases with respect to the total area of the Belgorod region is estimated at $0.28 \%$ for 10 years. In the near future it is planned to establish new quarries for opencast mining or iron ore in the Chernyansky and Novooskolsky districts of the region.

\section{The rates of anthropogenic transformation and the predicted tome of total exhaustion of the components of natural geosystems}

Based on taking into account the rates of anthropogenic losses of the Belgorod region's natural-resource potential, the time was calculated, for which total disappearance of the natural components of the region's natural environment is forecasted provided the previous intensity of their economic exploitation remains unchanged. According to calculations, the remaining steppe vegetation and also forests will disappear the fastest (within 73 days and 80 years, respectively). The rivers in the Belgorod region can disappear altogether within 670 years. Te humus reserves contained by the onemeter thick layer of all arable soils (on flat and sloping lands) will be exhausted within 810 years of their extensive exploitation. The abiogenic components of natural environment, i.e. the relief and rocks, will be changing markedly more slowly. Sheet erosion of fine earth materials down to the level of bedrock will terminate within 2500 years. Quarries- and dump-induced transformation of the lithogenic framework of landscapes can be completed within 3570 years. Total replacement of the sloping lands by gullies can only occur within 11110 years.

Our calculations demonstrated that the pace of development of quarries and dumps will exceed the rate of gullying and sheet erosion of fine earth materials. For tat reason, if the mining operations proceed at such a fast rate, they will prevent the manifestations of the anthropogenic lithomorphogenesis under consideration from being realized in full measure. We emphasize that the combined effects of the operation of quarries and dumps, gullying and sheet erosion of the ploughed-up slopes is able to lead to total degradation of the geomorphological framework of the natural geosystems within a shorter period of time.

\section{Conclusion}

Our study lends further support to the validity of V. I. Vernadsky's view that the contemporaneous civilization introduces grandiose modifications into the biosphere [41]. Thus, the natural vegetation cover in the Belgorod region could be entirely destroyed for 400 years (from 1600 to 1900), a period comparable with the formation duration of a climax forest association [14, 42]. According to our calculations, the river network that has existed on the territory of the region since the time of northward retreat of the Palaeothetis (about 30 million years) will wholly degrade during 1000 years of economic development. Humus contained in the one-meter thick layer of all arable soils in the region would disappear within 1350 years of their extensive development (from the start of ploughing), and total degradation of the humus state on the slopes and plakors, respectively, would occur within 1000 and 1700 years. It should be noted that natural fertility of soil cover was forming over the course of the Holocene (for the last 103000 years of the Earth's history).

The age of earth materials as deep as the ploughing up of the quarries is millions and several hundred million years. As a result of the economic activities, total transformation of the lithogenic base would occur within 3600 years.

It was established that the pace of anthropogenic withdrawal of the natural resources in the Belgorod region was decreasing in the biogenic components - bioinert components - abiogenic components series, which is quite natural, because the biogenic and bioinert landscape components are active accumulators of solar energy as well as vital substances for humans (vegetation, soils, river waters). Extraction and utilization of solar energy accumulated by them, and also their utilization as the means of production and food 
was the simplest and the most convenient way of man's existence in natural landscape. Later periods saw an increase of the set of components used and the depth of penetration of anthropogenic impacts into the landscape envelope.

A harmonization of the society - nature interaction occurring during the last several decades induces us to hope that the degradation process of natural-resource potential would cease. There is some evidence already that uncontrolled destruction of natural environment can be controlled. For instance, total degradation of the natural vegetation cover in the Belgorod region could occur at the end of the $20^{\text {th }}$ century, but this disaster was prevented by a well-considered reduction in the area of virgin steppes and forests in the 1880s and early in the $20^{\text {th }}$ century, respectively. These examples induce us to look forward to better prospects for the foreststeppe south of the Middle Russian Upland than predicted by these authors.

\section{References}

1. Boikov M. A Brief Geographical and Historical Overview of the Kursk Guberniya. Belgorod, 1879, 44 p.

2. Lopatin I. D. The agricultural Districts of the Kursk Guberniya. Kursk, 1923, 120 p.

3. Oganovsky N. The regularity of Agrarian Evolution. Studies on the History of Land Relations in Russia. Saratov, 1911, pt. 2, $632 \mathrm{p}$.

4. Savelieva L. E. Toward determination of lead levels in soils of technogenic landscapes (Belgorod and Kursk regions). In: Heavy Metals in the Environment. Moscow: Izd-vo Mosk. unta, 1980, pp. 63-69.

5. Chendev Yu. G. Temporal Changes of the Components of Geographical Environment in the Belgorod Region: A Textbook. Belgorod: Izd-vo Belgorod. un-ta, 1997, 84 p.

6. Nekrich A. S. Disturbances of natural environment in areas of iron ore mining in the Belgorod region. Izv. RAN. Ser. geogr., 2006, No. 6, pp. 81-87.

7. Petin A. N., Grigoriev G. N., Novykh L. L. et al. The natural conditions and resources of the Belgorod region. Studies of Local Lore, History and Development of the Belgorod Region. Belgorod: Izd-vo Belgorod. un-ta, 2000, pp. 213-262.

8. Fedotov V. I. technogenic Landscapes: Theory, Regional Structures, Practice. Voronezh: Izd-vo Voronezh. un-ta, 1985, 191 p.

9. Chendev Yu. G. The natural complexes of the pre-historic period (16 ${ }^{\text {th }}$ century). Atlas "The Natural Resources and Ecological State of the Belgorod Region”. Belgorod, 2005, pp. 18-19.

10. Zagorovsky V. P. The History of Accession of the Central BlackEarth Zone to the Russian State in the $16^{\text {th }}$ Century. Voronezh: Izd-vo Voronezh. un-ta, 1991, $270 \mathrm{p}$.

11. Chendev Yu. G. and Gennadiev A. N. States and trends of technogenic transformation of the soil cover of the Central ForestSteppe (Belgorod region). Vestn. Mosk. un-ta. Ser. 5. Geografiya, 1993, No. 2, pp. 29-37.

12. Wrangel V. The History of Forest Legislation of the Russian Empire and a Study of Ship Timber Forests of Russia. SPb, $1844,153 \mathrm{p}$

13. Topographic Description of the Kursk Region Ruled by Governor-General. TsGVIA, 1785. Stock VUA 249 (14842), 18799 storage items.
14. Neshatayev Yu. N., Dobretsov L. A. and Samiliak S. I. Biological productivity and its seasonal dynamics in different layers of oak forest. In: Biological Productivity and Its Factors in a Forest-Steppe Oakery. Leningrad: Izd-vo Leningr. Un-ta, 1974, pp. 119-152.

15. Alekhin V. V. Vegetation of the Kursk Guberniya and Further Tasks of Its Study. Kursk: Sov. derevnya, 1926, 120 p.

16. Sukachev V. N. A study of the vegetation in the southeastern part of the Kursk Guberniya. Izv. Lesnogo in-ta. SPb, 1903, issue 9, pp. 2-229.

17. Akhtyrtsev B. P. and Solovichenko V. D. Changes of humus stock in forest-steppe and steppe soils under the influence of intensive agricultural utilization and water erosion. Pochvovedeniye, 1984, No. 3, pp. 13-25.

18. Chendev Yu. G. and Kriushin V. P. Spatio-temporal changes in some of the chernozems of the Eastern-European Plain. Izv. RAN. Ser. geogr., 2007, No. 1, pp. 73-82.

19. Chendev Yu. G. and Petin A. N. Natural Changes and Technogenic Transformation of the Components of Environment of the Previously Developed Districts (Exemplified by the Belgorod Region). Moscow: Izd-vo Mosk. un-ta, 2006, $124 \mathrm{p}$.

20. Chendev Yu. G., Avramenko P. M. and Litsukov S. D. Changes of the humus state of arable soils in the Belgorod region. Agrokhimiya, 1998, No. 6, pp. 12-20.

21. Plan-Atlas of the Belgorod Uyezd of the Kursk Region Ruled by Governor-General. Sc. 1:84 000. PGADA, 1785. Stock $1356,155,156$ storage items.

22. Plan-Atlas of the Biryuchsky Uyezd of the Voronezh Region Ruled by Governor-General. Sc. 1:84 000. PGADA, 1789. Stock 1356, 632-635 storage items.

23. Plan-Atlas of the Bogatinsky Uyezd of the Kursk Region Ruled by Governor-General. Sc. 1:84 000. PGADA, 1785. Stock 1356, 157-159 storage items.

24. Plan-Atlas of the Valuisky Uyezd of the Voronezh Region Ruled by Governor-General. Sc. 1:84 000. PGADA, 1789. Stock 1356, 698-702 storage items.

25. Plan-Atlas of the Volchansky Uyezd of the Kharkov Region Ruled by Governor-General. Sc. 1:84 000. PGADA, 1784. Stock 1356, 353-355 storage items.

26. Plan-Atlas of the Belgorod Uyezd of the Kharkov Region Ruled by Governor-General. Sc. 1:84 000. PGADA, 1784. Stock 1356, 356, 357 storage items.

27. Plan-Atlas of the Kalitvinsky Uyezd of the Voronezh Region Ruled by Governor-General. Sc. 1:84 000. PGADA, 1789. Stock 1356, 758 storage items.

28. Plan-Atlas of the Korotoyaksky Uyezd of the Voronezh Region Ruled by Governor-General. Sc. 1:84 000. PGADA, 1789. Stock 1356, 766-768 storage items.

29. Plan-Atlas of the Korochansky Uyezd of the Kursk Region Ruled by Governor-General. Sc. 1:84 000. PGADA, 1785. Stock 1356, 162-165 storage items.

30. Plan-Atlas of the Miropolsky Uyezd of the Kharkov Region Ruled by Governor-General. Sc. 1:84 000. PGADA, 1783. Stock 1356, 366 storage items.

31. Plan-Atlas of the Nizhnedevitsky Uyezd of the Voronezh Region Ruled by Governor-General. Sc. 1:84 000. PGADA, 1789. Stock 1356, 801-802 storage items.

32. Plan-Atlas of the Novooskolsky Uyezd of the Kursk Region Ruled by Governor-General. Sc. 1:84 000. PGADA, 1786. Stock 1356, 801, 802 storage items. 
33. Plan-Atlas of the Oboyansky Uyezd of the Kursk Region Ruled by Governor-General. Sc. 1:84 000. PGADA, 1785. Stock 1356, 172 storage items.

34. Plan-Atlas of the Starooskolsky Uyezd of the Kursk Region Ruled by Governor-General. Sc. 1:84 000. PGADA, 1785. Stock 1356, 181-183 storage items.

35. Plan-Atlas of the Timsky Uyezd of the Kursk Region Ruled by Governor-General. Sc. 1:84 000. PGADA, 1785. Stock 1356, 179 storage items.

36. Plan-Atlas of the Khotmyzhsky Uyezd of the Kharkov Region Ruled by Governor-General. Sc. 1:84 000. PGADA, 1784. Stock 1356, 373, 374 storage items.

37. Topographic Map of the Belgorod Region. Sc. 1:200 000. Moscow: TsEVKF, 1998, 32 p.
38. Chendev Yu. G. and Petin A. N. Losses of mineral components of landscape in the south of the Middle Russian Upland. In: Nature Management Economics of the Altai Region: History, Present, Prospects. Barnaul, 2000, pp. 182-186.

39. Gennadiev A. N. Soil and Time: Models of Development. Moscow: Izd-vo Mosk. un-ta, 1990, 229 p.

40. Dunayev V. A., Sery S. S., Frolov A. P. et al. Mineral resources of the sedimentary mantle of the platform. Atlas "The Natural Resources and Ecological State of the Belgorod Region”. Belgorod, 2005, pp. 30-31.

41. Vernadsky V. I. Biosphere (Selected Works on Biogeochemistry). Moscow: Mys1, 1967, 375 p.

42. Kovda V. A. Biogeochemistry of Soil Cover. Moscow: Nauka, $1985,264 \mathrm{p}$. 